\title{
Uma idéia sobre a municipalização do ensino
}

\section{JOSÉ MÁRIO PIRES AZANHA}

A

tese e a luta pela municipalização do ensino de $1^{0}$ Grau são muito antigas no Brasil, mas podemos tomar como um mar1957, ele apresentou suas idéias num Congresso Nacional de Municipalidades, cujo exame faremos em seguida, muito brevemente (1).

As idéias de A. Teixeira sobre o assunto eram muito claras e poderão ser resumidas nos seguintes itens:

a) a municipalização abrangeria apenas o antigo ensino primário (na época, o ensino pré-primário era algo muito distante e irrealizável). Com relação ao ensino primário, o município teria as atribuiçōes de organização, administração e execução. Apenas a supervisão ficaria a cargo do Estado;

b) o desempenho das atribuiçóes municipais de educação ficaria a cargo de um Conselho de Educação. Na ordenaçăo do ensino municipal, o Conselho local atenderia às normas de uma lei orgânica do ensino elaborada por um Conselho Estadual de Educação em consonância com as diretrizes e bases da educação nacional, interpretadas por um Conselho Federal de Educação;

c) ao Conselho Municipal de Educação caberia a determinação do custo do aluno nas escolas do município e a fixaçáo da cota municipal de contribuição possível para fazer face a esse custo. A complementação desses recursos seria feita pela transferência ao município de uma cota estadual e de uma cota federal. Para administração desses recursos haveria, em cada esfera, os respectivos fundos de educaçáo;

d) para A. Teixeira, a municipalização do ensino primário ofereceria vantagens de ordem administrativa, social e pedagógica. Quanto à primeira, as razóes são óbvias. Quanto à segunda, as vantagens adviriam do fato do professor ser um elemento local ou pelo menos aí integrado e não mais um consul representante de um poder externo. Quanto à terceira, residiria 
principalmente na possibilidade do currículo escolar refletir a cultura local.

Não obstante a brevidade do resumo, pode-se perceber que $A$. Teixeira tinha sobre o tema da municipalização do ensino um conjunto coerente de idéias. Não pretendemos fazer uma análise do modelo proposto, mas apenas ressaltar que, para o autor, a municipalizaçáo do ensino era a resposta a uma situaçăo a ser modificada, a fim de que o ensino primário reunisse condiçóes de melhoria de padráo que, de outro modo, não parecia viável. Inspirado na educação norte-americana, de tradiçōes fortemente locais, pareceu a A. Teixeira que uma reordenaçáo das responsabilidades municipal, estadual e federal seria suficiente para que a instituiçáo escolar de nível primário se fortalecesse e se consolidasse. Sabemos, hoje, que essa visão era um pouco simplista e algo romântica, porque ignorava, deliberadamente, toda a complexidade do jogo político que cerca o traçado de uma política educacional de dimensóes tấo amplas.

Mas, em que pese a singeleza do modelo proposto, nele a municipalização tinha um propósito claro: a melhoria do ensino primário. Desde então, até os nossos dias, essa clareza foi sendo perdida e nem sempre é fácil saber o que se pretende quando se fala em municipalizaçáo do ensino, como examinaremos, sinteticamente, em alguns pontos:

1. Em primeiro lugar, é preciso lembrar que, após A. Teixeira, o tema da municipalizaçáo saiu de moda por muitos anos e não são poucos aqueles que interpretam o seu retorno aos debates educacionais como expressão da vontade política de fragmentaçáo dos movimentos sindicais do magistério. Embora essa interpretação possa ter seu grão de verdade, é inegável que o tema da municipalização do ensino é também um componente de um pathos participativo. Após duas décadas de uma ordenaçấo legal autoritária da vida nacional, há uma ânsia participativa em torno da qual têm se congregado todas as camadas da população. Hoje, há até um mito da participaçáo como se apenas as iniciativas que dela decorressem fossem válidas e aceitáveis, até mesmo quando a complexidade do assunto pudesse não recomendar simples decisóes consensuais, frutos de esforços participativos. Como integrante desse pa. thos, o termo municipalizafáo se relaciona fortemente com outros como descentralizafáio, desconcentrafáo, consenso, etc., todos eles positivamente valorizados, como se invariavelmente indicassem maior democratização e, também, maior racionalização. Todos sabemos que as coisas náo são bem assim e que a simples administraçáo local do ensino não representa por si só nenhuma garantia de sua efetiva democratização e pode até mesmo ser oportunidade de exercício de formas mais duras de coerção 
sobre o processo educativo e sobre o magistério.

2. Nesse quadro, em que a municipalização do ensino se transformou muito mais numa bandeira do participacionismo do que num projeto educacional, é preciso um esforço no sentido de impedir que a exploração política do tema nos conduza a um desmantelamento nãoseletivo e, por isso mesmo, não-racional do sistema estadual do ensino de 1\% Grau. Municipalizafaro do ensino é apenas uma expressão abstrata e, nessas condiçóes, nada indica que deva provocar reaçóes de apoio ou de desaprovaçáo. É preciso - como fez Anísio Teixeira - que indiquemos claramente quais sáo os problemas que se pretende resolver com uma política municipalista em educação. Sem isso, a retórica pró-municipalização, como também a retórica antimunicipalização são inteiramente vazias, năo obstante o tecnicismo de que se revistam e, eventualmente, podem até ensejar fortes prejuízos à causa educacional. Contudo, foi nesse quadro que as constituiçóes federal e estadual instituíram a municipalização do ensino. Mais ainda, ambas as constituiçóes falam em sistemas municipais de ensino de maneira genérica e ambígua o que, eventualmente, poderá contribuir para aumentar a confusáo com relação ao tema.

3. Já em 1968, a Lei no 10.125, que instituiu o Código de Educaçáo do Estado de São Paulo, distinguia claramente sistema de ensino e rede de escolas, conceituando aquele como o "conjunto de normas que disciplinam, em seus vários aspectos o processo educativo" . Essa distinçáo entre a noçáo restrita de sistema de ensino e a de rede escolar é útil para um clareamento do assunto, porque permite o estabelecimento de coordenadas claras para projetos de municipalizaçáo do ensino. É evidente que municipalizar o ensino, instituindo um sistema próprio num sentido amplo, é coisa muito diferente de municipalizar o ensino apenas assumindo a administração de uma rede de escolas. Não obstante a lingua-

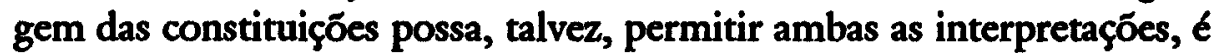
de se crer que, após a promulgação de uma nova lei de diretrizes e bases da educaçáo nacional e da lei que organizará o Sistema de Ensino do Estado de São Paulo, como está estabelecido nas constituiçōes, escassa será a margem de liberdade para que os municípios organizem os seus sistemas de ensino num sentido amplo. Os projetos de municipalizaçăo terão de se ater às ordenações dessas leis maiores. Mas talvez não haja nesse cerceamento legal um mal maior, se houver uma mobilização do poder de pressáo dos munićpios, no sentido de impedir que as futuras leis, antes referidas, estabeleçam de forma sufocante a parte obrigatória do currículo. É preciso assegurar que a um núcleo comum, obrigatório e, por isso, nacional, nada mais seja imposto pelos conselhos federal e 
estaduais de educação. Somente assim, em cada município, as escolas poderáo oferecer, ao invés de um currículo amplo e de mentira, aquele outro que refletirá as tradiçóes locais e as possibilidades efetivas de cada município. Nem se diga que isto comprometerá uma unidade nacional desejável e que municípios pobres teriam um currículo empobrecido. Não há unidade curricular nacional construída sobre a mentira e o fazde-conta. Se um município náo tiver condiçóes de enriquecer um currículo nuclear e obrigatório, a simples ampliação do estudo da língua nacional teria um alto efeito educativo.

4. Mas, realmente fundamental, para que a municipalização do ensino não seja um projeto utópico e nem uma retórica a serviço de interesses que nada têm a ver com ensino, é necessário que principiemos a discussáo do assunto com a idéia de que a municipalização só é defensável se puder contribuir para a melhoria do ensino, como queria $\mathrm{A}$. Teixeira. Nesse sentido, o passo inicial é municipalizar a preocupação com o problema educacional. Sem isso, tudo o mais é tempo perdido. Não há e nem haverá providência legal que substitua o sentimento coletivo de que é urgente melhorar o nível educativo de nossas escolas. Este é o ponto central do problema.

Nessas condiçóes, a discussáo da municipalizaçáo do ensino a partir de consideraçóes tributárias, políticas e administrativas ou a partir de consideraçóes abstratas sobre centralização, descentralização, etc. significa um rodeio daquilo que é essencial e poderia ser esclarecido pelo esforço em responder à seguinte questáo: Como pode a municipalização contribuir para uma efetiva melhoria da escola pública de $1^{\circ}$ Grau?

Antes de fazer uma tentativa no sentido de responder a essa questão central, convém fazer algumas consideraçóes sobre a própria escola pública paulista.

5. Todos sabemos que é grave a crise do ensino público brasileiro. Mas, é bom lembrar que, em termos de Brasil, essa crise, que é antiga, se dilui e se amolda a um panorama nacional de pobreza e de arcaísmo das instituiçóes sociais vigentes, historicamente consolidadas por tradiçôes de autoritarismo e de opressão. Por isso, já em 1953, Abgar Renault, falando sobre a crise do ensino brasileiro, perguntava:

"...como exigir e esperar que o nosso ensino seja bom, isto é, superior às demais coisas que possuímos? Que instituição nacional funciona melhor do que ele?" (2).

Em Sáo Paulo, porém, o quadro geral é outro e por isso a atual crise da escola pública assume proporçóes que parecem catastróficas, porque 
a riqueza do Estado, os padrōes de vida e novas formas de relacionamento social já alcançados em outros setores contrastam fortemente com os sinais de falência da instituiçáo escolar que, segundo se diz, em outras épocas foi excelente e até modelar. Esse é o quadro da escola pública que todos conhecem, que a imprensa comenta e que vem compondo uma imagem do ensino público como um ensino falido. Será, porém, que essa imagem é inteiramente real? Será que o destino da escola pública paulista já está irremediavelmente traçado, tal como o descreve o crescente processo de estigmatizaçăo da instituiçăo?

Náo o cremos. Não acreditamos que a escola pública já seja uma instituição falida, embora não se possa deixar de reconhecer que, a persistir o quadro atual, a falência talvez seja inevitável porque, na última década do século, a escola paulista de $1 \%$ Grau ainda não abrange toda a população escolarizável e mesmo aquela parcela que é alcançada acaba, em proporçóes significativas, sendo expulsa pela evasão e pela repetência. E mesmo aqueles que sobrevivem a essa dizimação pedagogica terminam o seu curso pouco além do limiar do analfabetismo ou, pelo menos, em estado indiscutível de penúria cultural.

Quando, há décadas, A. Teixeira escreveu um livro de combate: Educaf̧ão não é privilégio, ele pretendia denunciar a alarmante situação da escola primária brasileira cuja composiçáo de matrícula da $1^{\text {a }}$ à $4^{\text {a }}$ série assemelhava-se a uma pirâmide. Muitos entravam na $1^{\text {a }}$ série, mas poucos concluíam o curso. O restante perdia-se pela evasão e pela repetência, como hoje. Era assim no Brasil e era assim em São Paulo.

A grande diferença entre a situaçáo atual e essa situaçáo passada é que, então, a escola era aceita como privilégio e desempenhava uma conveniente função de discriminação social: expulsava os pobres e conservava os privilegiados. Por isso, a escola de antigamente, que também nem era táo boa quanto se imagina e se alardeia, era aceita porque servia aos privilegiados que, em casa, tinham um ambiente cultural que supria as deficiências do ensino escolar. Mas, hoje, essa paisagem foi profundamente alterada pelas grandes transformaçóes socioeconômicas ocorridas em Sáo Paulo nas últimas décadas. Grandes contingentes populacionais chegaram ao Estado. A escola pública estendeu-se para abranger uma população que nunca antes procurara a escola mas que, agora, necessitava dela para assimilar os elementos culturais mínimos para poder integrar-se ao mercado de trabalho.

Nesse quadro é que a crise atual da educaçáo paulista assume proporçốes alarmantes porque, para a imensa maioria da populaçáo que procura a escola pública, ela é um complemento único e por isso indis- 
pensável ao próprio processo de socialização da criança, cujos pais, erradicados de sua própria cultura e socialmente desagregados num ambiente estranho, são obrigados a jornadas de trabalho que inviabilizam uma convivência familiar satisfatória. Com essa convivência familiar prejudicada e sem a convivência social que a escola poderia e deveria proporcionar, a criança assimila, pelas ruas, padróes anti-sociais de comportamentos. Nessas condiçóes, a escola pública não pode falhar porque, se é verdade que é muito difícil a determinação do valor relativo da educaçáo como elemento de ascensão social, um ponto é indiscutível: a ausência da educaçáo num meio social altamente urbanizado é devastadora e marginalizante.

6. A atual situação do ensino de $1^{\circ}$ Grau em São Paulo é a resultante de anos seguidos da conjugação de erros governamentais, de interesses corporativistas mesquinhos e de uma incompreensível ausência de responsabilidade cívica de grande parte da sociedade. Em face dos propósitos visados, vamos deter a nossa atenção apenas na irresponsabilidade cívica com relação aos destinos da escola pública. Porque é com relaçáo a esse ponto que pretendemos tentar responder à questáo sobre a possível contribuição que a municipalizaçáo do ensino pode dar para reverter a atual situação da escola pública.

Essa contribuição será uma decorrência do modo de conceber a municipalizaçáo. Como dissemos anteriormente, o fundamental é municipalizar a preocupação com o problema educacional e isso não será feito por nenhuma providência legal. A municipalização precisa consistir num movimento de convocação e mobilização de todos os setores da sociedade local no sentido de salvaçáo da escola pública. E isso, evidentemente, só tangencialmente está ligado à administraçáo do ensino e à construção ou reforma de prédios escolares. Dentre os fatores desencadeantes da crise da escola pública, há componentes psicossociais muito fortes e que poderiam ser designados pela expressão falta de compromisst com a escola priblica. Falta de compromisso profissional e político do magistério e falta de compromisso cívico de toda a comunidade. É uma questáo de mentalidade. Não há mais tempo a perder. Em matéria de educação pública, atingimos um ponto-limite. Além dele, é possível a tragédia e a convulsão social. Ou salvamos a escola pública ou fixaremos um destino de miséria física e social para milhóes de crianças.

Por isso, não há mais desculpas para ninguém que detenha alguma parcela de responsabilidade civil. A questão da qualidade do ensino há muito deixou de ser simples assunto técnico para emergir como questáo relevante e premente de interesse público e, nessas condições, precisa ser enfrentada pela própria sociedade como um todo. Nenhuma violên- 
cia possível sobrepassa em efeitos sociais duradouros a reprovação maciça e a evasão de milhóes de alunos, mas as comunidades têm permanecido insensíveis diante dessa situação. No entanto, é com freqüência que se assiste à mobilização da sociedade $\mathrm{em}$ face de ameaças à natureza. Mas, a verdade é que a espécie humana também faz parte dessa natureza que tanto nos preocupa. A preocupação ecológica precisa alcançar, também, as crianças, indiscutivelmente, muito mais valiosas do que baleias e jacarés. Por isso, a municipalizaçáo do ensino precisa, antes de qualquer outra providência, constituir-se numa mobilização social intensa e sistemática na defesa da escola pública.

7. É claro, porém, que esse movimento năo pode ser uma açáo social exterior à escola, como quem levanta um corpo inerte. A municipalização do ensino será uma violência se tiver a pretensão e a arrogância de interferir na escola, ainda que com o propósito de melhorá-la. A condução da escola é um assunto de educadores.

A escola pública paulista não é uma vala comum de instituiçóes falidas. Há muitas escolas públicas que ainda mantêm padróes de excelência $\mathrm{e}$, mesmo naquelas ruins, há pelo menos alguns profissionais também excelentes. O que é preciso é assegurar às escolas apoio técnico, financeiro e social para que elas próprias avaliem as suas deficiências e se reorganizem para superá-las. A municipalização do ensino, nessas condiçóes, deve ter um duplo propósito: $1^{\circ}$ ) mobilizar a sociedade local no sentido de despertar a consciência de suas responsabilidades com relação à escola pública; $2^{\circ}$ ) pressionar políticos e governos para que a escola pública tenha apoio técnico e financeiro para assumir sua autonomia pela elaboração e execução de seus próprios projetos pedagógicos, capazes de eliminarem deficiências e falhas da instituição.

\section{Notas}

1 Teixeira, A. - "A municipalizaçăo do ensino primário" in Revista Brasileira de Estudos Pedagggicos, vol. XXVII, abril-junho, 1957, n 66.

2 Renault, A. - "A crise do ensino brasileiro" in Revista Brasileira de Estudos Pedagtgicos, vol. XIX, abril-junho, 1953, n 56.

\section{Resumo}

O artigo mostra que a municipalizaçāo do ensino, no pensamento de Anísio Teixeira, visava claramamente à melhoria do ensino. Hoje, porém, a municipalização é muito mais uma bandeira do participacionismo do que um projeto de reoordenaçáo legal das responsabilidades públicas em matéria de educação. 


\section{Abstratc}

The article shows that the control of education by the municipality, in Anísio Teixeira's point of view, aimed at the improvement of education. Today, however, this control is much more an opportunistic attitude of those in the charge of the municipality than a project to legally reorganize the public duties concerning education.

José Mário Pires Azanha é professor da Faculdade de Educação da USP. Palestra feita pelo autor em agosto de 1990 na Fundação do Desenvolvimento Administrativo (FUNDAP). 